УДК 612.014.482-053.2-085.252-084:546.15

DOI https://doi.org/10.11603/2312-0967.2020.1.10904

\title{
ОБҐРУНТУВАННЯ ФАРМАЦЕВТИЧНОЇ РОЗРОБКИ ЛІКАРСЬКОГО ЗАСОБУ ДЛЯ ПРОВЕДЕННЯ ЙОДНОЇ ПРОФІЛАКТИКИ РАДІАЦІЙНИХ УРАЖЕНЬ У ДІТЕЙ
}

\author{
Д. В. Вороненко걱. А. Шостак², С. Б. Білоус ${ }^{2}$, П. В. Олійник² \\ Українська військово-медична академія ${ }^{1}$, Київ \\ Львівський національний медичний університет імені Данила Галицького 2 \\ petrolinik1@gmail.com
}

\section{ІНФОРМАЦІЯ}

Надійшла до редакції / Received: 17.01 .2020

Після доопрацювання / Revised: 07.02.2020

Прийнято до друку / Accepted: 14.02.2020

\section{Ключові слова:}

радіаційна аварія;

йодна профрілактика;

новонароджені діти і немовлята; калію йодид.

\begin{abstract}
АНОТАЦІЯ
Мета роботи. Обґрунтування необхідності розширення асортименту лікарських засобів для йодної профрілактики у випадку радіаційних аварій. Матеріали і методи. Застосовували методи інорормаційного пошуку, систематизації, контент-аналізу, порівняння та узагальнення.

Результати й обговорення. За результатами аналізу асортименту препаратів із калію йодидом станом на 1 грудня 2019 року встановлено, що на українському фрармацевтичному ринку зареєстровано 30 позицій 3 калію йодидом у вигляді 7 лікарських фрорм. Зареєстровані препарати призначені для лікування захворювань щитоподібної залози та профрілактики йодного десріциту і містять дозу стабільного йоду 100-200 мкг, що недостатньо для профрілактики радіаційних уражень. Обґрунтовано необхідність розробки рідких лікарських засобів із калію йодидом у фрормі перорального розчину екстемпорального виготовлення або промислового виробництва для проведення йодної профрілактики дитячому населенню та дітям у пологових будинках, дитячих лікарнях та інших дитячих закладах. Запропоновано впровадження промислового виробництва перорального розчину з концентрацією калію йодиду 65 мг/мл (6,5%). У аптеках із правом екстемпорального виготовлення лікарських засобів у випадку отримання повідомлення про радіаційну аварію запропоновано виготовляти 0,65 \% і 0,32 \% розчини калію йодиду для профрілактики радіаційних уражень у дітей різного віку.

Висновки. Встановлено відсутність на українському фрармацевтичному ринку препаратів калію йодиду для захисту новонароджених та дітей до 3-х років від радіаційних уражень щитоподібної залози. 3 урахуванням міжнародних та національних вимог обґрунтовано необхідність розробки рідких пероральних лікарських засобів із калію йодидом промислового виробництва або екстемпорального виготовлення для проведення йодної профрілактики дітям віком від народження до 3 років.
\end{abstract}

Вступ. Збройний конфлікт на сході України, наявність зовнішньої збройної агресії та пов'язаних з нею терористичних загроз свідчить про можливість вчинення актів ядерного тероризму і виникнення масштабних радіаційних аварій (РА) на ядерних об'єктах України. У випадку РА відбувається викид радіоактивних продуктів у навколишнє середовище, в тому числі значної кількості радіоактивних ізотопів

ISSN 2312-0967. Фармацевтичний часопис. 2020. № 1 
йоду (131-135I), які будуть потрапляти в організм людини на початковому етапі аварії інгаляційно, а потім перорально з продуктами харчування (перш за все 3 молоком).

Профрілактика радіаційних уражень за допомогою препаратів стабільного йоду є захисним заходом і входить у план загального реагування на радіаційну аварію [1]. Застосування йодної профрілактики спрямоване на попередження поглинання радіоактивних ізотопів йоду щитоподібною залозою [1-4]. Проведений аналіз свідчить про відсутність зареєстрованих в Україні лікарських засобів йодиду калію для дітей у вигляді пероральних рідких лікарських фрорм.

Мета роботи - обґрунтування необхідності розширення асортименту лікарських засобів для проведення йодної профрілактики, зокрема дитячому населенню, у вигляді перорального лікарського засобу та обґрунтування кількості активного фрармацевтичного інгредієнта у його складі.

Матеріали і методи. Для досягнення поставленої мети проведено огляд вітчизняних і зарубіжних наукових джерел та нормативно-правових актів. Під час виконання дослідження застосовували методи інфрормаційного пошуку, систематизації, контент-аналізу, порівняння та узагальнення.

Результати й обговорення. У дітей у зв'язку 3 більш високою функціональною активністю і меншими розмірами щитоподібної залози, з відносно високими величинами хвилинного об'єму дихання, ніж у дорослої людини, накопичення радіоактивного йоду в щитоподібної залозі відбувається значно швидше. Активні ігри з іграшками безпосередньо на поверхні землі зумовлюють інтенсивний контакт із приземним шаром атмосорери, де у випадку РА утворюється висока концентрація радіоактивних речовин. Окрім того, молочні продукти в раціоні харчування дітей, особливо немовлят, зумовлюють ризик надходження в дитячий організм ізотопів радіоактивного йоду, які 3'являються у продуктах харчування після надхо-
Фармацевтична технологія, біофармація, гомеопатія Pharmaceutical technology, biopharmacy, homeopathy

дження до навколишнього середовища, тому захист дітей повинен бути пріоритетним при проведенні йодної профрілактики серед населення [5].

Відповідно до наказу Державної інспекції ядерного регулювання України № 154 від 08.11.2011 р. «Про затвердження Порядку здійснення невідкладних заходів йодної профрілактики серед населення України у разі виникнення радіаційної аварії» йодна профрілактика у випадку РА полягає у терміновому введенні в організм людини препарату йодиду калію 3 метою запобігання або зменшення поглинання радіоактивних ізотопів йоду щитоподібною залозою [1]. Проте у наказі не вказано порядку дозування калію йодиду як засобу профілактики радіаційних уражень для різних вікових категорій населення. Відповідно до вимог даного наказу, у випадку виникнення РА схеми видачі препаратів йодиду калію повинні розраховуватись та уточнюватись при проведенні практичних занять і тренувань територіальних підсистем єдиної системи цивільного захисту [1].

У США, відповідно до рекомендацій Управління 3 контролю за якістю харчових продуктів і лікарських препаратів (US Food and Drug Administration - FDA), калію йодид рекомендується приймати один раз на добу у відповідних дозуваннях, залежно від віку, що забезпечує повноцінну блокаду щитоподібної залози протягом доби [2, 3]. Дози калію йодиду, рекомендовані FDA для різних груп населення, наведено в таблиці 1 [3].

ВОО3, відповідно до Рекомендацій для йодної профрілактики внаслідок радіаційних аварій, розроблених у 1999 р. [4], також пропонує застосування калію йодиду у відповідних дозах залежно від віку (табл. 2).

За даними таблиць 1 та 2, дози калію йодиду, які рекомендуються FDA та BOO3 застосовувати для дітей у випадку РА, дещо відрізняються. Відповідно до рекомендацій FDA доза калію йодиду для дітей віком від 12 до 18 років становить 65 мг (50 мг йоду), а від-

Таблиця 1

Дози калію йодиду, рекомендовані FDA, для різних груп населення

\begin{tabular}{|c|c|c|c|c|}
\hline Вікова група & $\begin{array}{l}\text { Доза KI } \\
\text { (мг) }\end{array}$ & $\begin{array}{c}\text { Кількість табл. } \\
130 \text { мг }\end{array}$ & $\begin{array}{c}\text { Кількість } \\
\text { табл. } 65 \text { мг }\end{array}$ & $\begin{array}{c}\text { К-ть перорального } \\
\text { р-ну, } 65 \text { мг / мл }\end{array}$ \\
\hline Дорослі, старше 40 років & 130 & 1 & 2 & 2 мл \\
\hline Дорослі (від 18 до 40 років) & 130 & 1 & 2 & 2 мл \\
\hline Вагітні або жінки, які годують & 130 & 1 & 2 & 2 мл \\
\hline Підлітки (від 12 до 18 років) & 65 & $1 / 2$ & 1 & 1 мл \\
\hline Діти (від 3 до 12 років) & 65 & $1 / 2$ & 1 & 1 мл \\
\hline Діти (від 1 місяця до 3 років) & 32 & $\begin{array}{c}\text { Рекомендовано } \\
\text { пероральний } \\
\text { розчин КІ }\end{array}$ & $1 / 2$ & 0,5 мл \\
\hline $\begin{array}{l}\text { Новонароджені (від народження } \\
\text { до } 1 \text { місяця) }\end{array}$ & 16 & $\begin{array}{c}\text { Рекомендовано } \\
\text { пероральний } \\
\text { розчин КІ }\end{array}$ & $\begin{array}{c}\text { Рекомендовано } \\
\text { пероральний } \\
\text { розчин КІ }\end{array}$ & 0,25 мл \\
\hline
\end{tabular}

ISSN 2312-0967. Pharmaceutical review. 2020. № 1 
Фармацевтична технологія, біофармація, гомеопатія Pharmaceutical technology, biopharmacy, homeopathy

Таблиця 2

Дози калію йодиду, рекомендовані ВОО3, для різних груп населення

\begin{tabular}{|l|c|c|c|}
\hline \multicolumn{1}{|c|}{ Вікова група } & Доза йоду, мг & Доза KІ, мг & Кількість табл. (100 мг йоду) \\
\hline Дорослі та діти від 12 років & 100 & 130 & 1 \\
\hline Діти (від 3 до 12 років) & 50 & 65 & $1 / 2$ \\
\hline Діти (від 1 місяця до 3 років) & 25 & 32 & $1 / 4$ \\
\hline Немовлята (від народження до 1 місяця) & 12,5 & 16 & $1 / 8$ \\
\hline
\end{tabular}

повідно до рекомендацій ВООЗ - доза калію йодиду для даної вікової категорії не відрізняється від дози для дорослих і становить 130 мг (100 мг йоду).

У США, відповідно до даних FDA, для проведення йодної профрілактики у дітей рекомендується застосування таблетованих препаратів із дозою калію йодиду 130 мг та 65 мг, а також перорального розчину 3 концентрацією калію йодиду 65 мг/мл, який можна застосовувати немовлятам та дорослим. ВООЗ рекомендує для дітей застосування таблеток калію йодиду з дозою 130 мг, шляхом розподілу їх на частини, залежно від віку дитини.

У публікаціях FDA також наводяться рекомендації з приготування розчину калію йодиду для дітей грудного і молодшого віку в домашніх умовах на основі таблеток калію йодиду по 130 мг та 65 мг (вміст йоду 100 мг та 50 мг відповідно), розчинивши їх у малиновому сиропі для усунення солоно-гіркого смаку калію йодиду. Термін придатності даного розчину 7 діб при зберіганні у холодильнику [6].

Проведений аналіз асортименту препаратів із калію йодидом відповідно до Державного реєстру лікарських засобів України станом на 1 грудня 2019 року дозволив встановити, що на українському фрармацевтичному ринку зареєстровано 30 позицій з калію йодидом у вигляді 7 лікарських фрорм [7]. Співвідношення лікарських засобів за лікарськими формами наведено на рисунку 1.

Із даного переліку лікарських засобів із калію йодидом за анатомо-терапевтичною хімічною класифрікацією (АТС-класифікацією) 5 лікарських засобів ре- комендуються при захворюваннях щитоподібної залози (Н03С): Калію йодид (табл. 250 мг № 10, ПАТ «Монфрарм», Україна), Йод-норміл (табл. 100 мкг, 200 мкг, АТ «Київський вітамінний завод», Україна), Антиструмін (табл. 1 мг № 50 та № 100, ПрАТ «Фармацевтична фрірма «Дарниця», Україна), Йодомарин (табл. 100 мкг , 200 мкг № 50, №100 «БЕРЛІН-ХЕМІ АГ», Німеччина), Йодид-Фармак (табл. 100 мкг, 200 мкг, № 50, ПАТ «Фармак», Україна). Серед даних лікарських засобів відповідно до інструкції для медичного застосування лише Калію йодид (табл. 250 мг № 10, ПАТ «Монфрарм») можна призначати дорослим та дітям віком від 2 років по 125 мг (1/2 таблетки) один раз на добу при загрозі надходження в організм радіоактивного йоду для захисту від опромінення щитоподібної залози; Йод-норміл, Йодомарин та Йодид-Фармак у табл. по 100 та 200 мкг рекомендується приймати немовлятам та дорослим для просрілактики розвитку дефріциту йоду або для лікування захворювань щитоподібної залози. Решту лікарських засобів 3 калію йодидом випускають у порошках (субстанції для виготовлення нестерильних лікарських засобів), очних краплях, розчинах для ротової порожнини, розчинах для зовнішнього застосування, краплях, капсулах, таблетках (полівітаміни) та розчину оромукозного.

Таким чином, на вітчизняному фармацевтичному ринку є зареєстровані препарати калію йодиду для застосування населенням територій з дефріцитом йоду (у питній воді і продуктах харчування), які містять дозу стабільного йоду 100-200 мкг. Проте доза калію йоди-

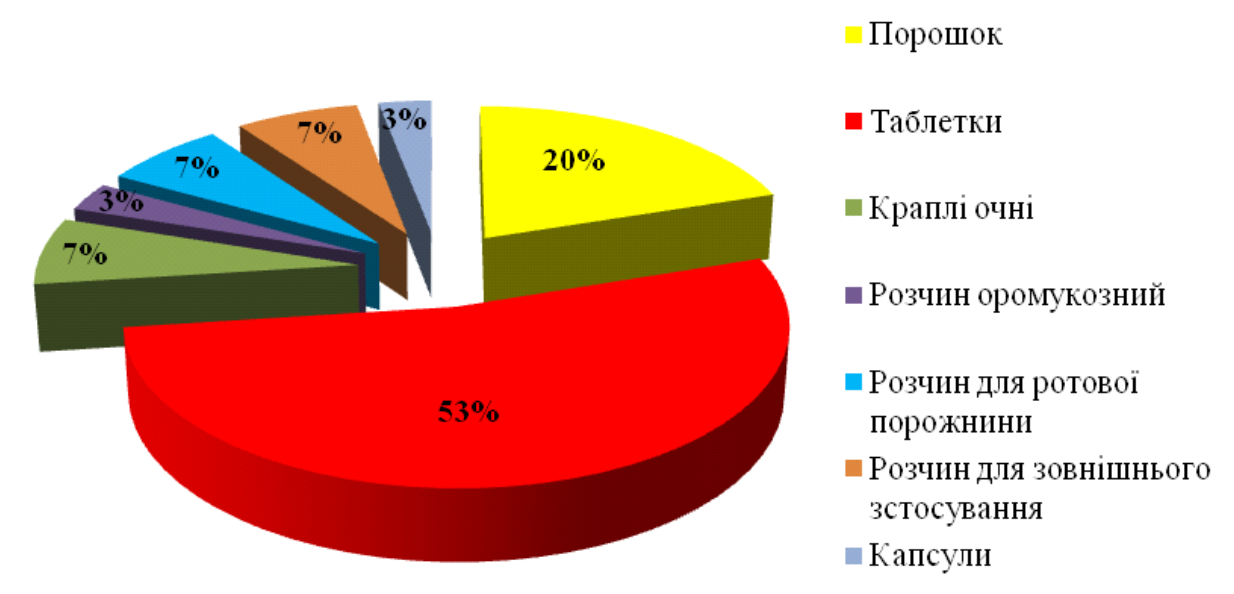

Рис. 1. Співвідношення лікарських засобів із калію йодидом за лікарськими формами.

ISSN 2312-0967. Фармацевтичний часопис. 2020. № 1 
ду для профрілактики радіаційного ураження і доза калію йодиду для профрілактичного застосування при екологічній недостатності мікроелемента відрізняються у 500-1000 разів. Застосування цих препаратів для профрілактики радіаційних уражень не можливе, тому що для блокування щитоподібної залози дорослій людині необхідно було б прийняти 1000 таблеток препарату призначеного для профілактичного застосування при екологічній недостатності йоду [5].

В Україні зареєстрований лише один препарат калію йодиду (таблетки калію йодиду 250 мг) придатний для проведення йодної профрілактики у випадку РА. Однак слід зазначити, що дози калію йодиду, які рекомендуються застосовувати для профрілактики радіаційних уражень, відповідно до інструкції для медичного застосування даного лікарського засобу, суттєво відрізняються від рекомендацій FDA та ВОО3, а йодна профрілактика для дітей до 2 років даним препаратом взагалі не передбачається.

Відповідно до Настанов «Вимоги до виготовлення нестерильних лікарських засобів в умовах аптек» та «Вимоги до виготовлення стерильних та асептичних лікарських засобів в умовах аптек», затверджених наказом МОЗ України № 398 від 01.07.2015 р., екстемпорально в аптеках можна виготовляти розчин калію йодиду 0,25 \% для внутрішнього застосування та розчин калію йодид 0,5 \% для внутрішнього застосування для немовлят [8, 9]. Однак рекомендовані концентрації розчинів зумовлюють труднощі при одержанні педіатричних доз йоду для проведення йодної профрілактики у випадку виникнення РА.

Оскільки таблетки калію йодиду по 130 мг та 65 мг не зареєстровані в Україні, а використання таблеток калію йодиду по 250 мг для профрілактики радіаційних уражень у дітей від 1 місяця до 3 років та новонароджених передбачає розділення таблеток на 8 або 16 частин відповідно, що не є можливим для одержання однорідних доз, то актуальною $є$ розробка рідких лікарських засобів із калію йодидом у формі перорального розчину екстемпорального виготовлення або промислового виробництва. Дана лікар-
Фармацевтична технологія, біофармація, гомеопатія Pharmaceutical technology, biopharmacy, homeopathy

ська фрорма широко застосовується у дитячій практиці, завдяки ряду переваг, а саме: зручність використання, рівномірність і швидкість всмоктування лікарських речовин, точність дозування тощо. Рідкі лікарські засоби з калію йодидом у фрормі перорального розчину екстемпорального виготовлення або промислового виробництва необхідні для проведення йодної профрілактики дітям у пологових будинках, дитячих лікарнях та інших дитячих закладах.

Враховуючи рекомендації FDA, як активний фрармацевтичний інгредієнт у пероральному розчині для промислового виробництва доцільно використати калію йодид 3 концентрацією 65 мг/мл (6,5 \% р-н), що дозволить використовувати лікарський засіб як новонародженим, так і дітям різного віку та дорослим. Розчин обов'язково має бути укомплектований дозуючим пристроєм 3 можливістю відміряти 0,25 мл розчину (доза для новонароджених).

В аптеках з правом екстемпорального виготовлення лікарських засобів у випадку отримання повідомлення про РА доцільно виготовляти розчини калію йодиду за наступними прописами: Sol. Kalii iodidi 0,65 \% - $100 \mathrm{ml}$ та Sol. Kalii iodidi 0,32 \% - $10 \mathrm{ml}$. Sterilisa! для профрілактики радіаційних уражень у дітей різного віку, що дозволить в домашніх умовах легко дозувати лікарський засіб - по 1 або 2 чайній ложці для дітей відповідного віку. Виготовлення розчину калію йодиду 3 концентрацією 0,32 \% повинно проводитись в асептичних умовах або з використанням ламінарного боксу, оскільки лікарські засоби для новонароджених мають бути стерильними [9].

При наявності в арсеналі таблеток калію йодиду по 250 мг та екстемпорально виготовлених розчинів із концентрацією калію йодиду 0,32 \% та 0,65 \%, схеми застосування препаратів йодиду калію для профрілактики радіаційних уражень для різних вікових груп населення будуть наступними (табл. 3).

Таблетки калію йодиду по 250 мг не рекомендується застосовувати для дітей до 3-х років, однак за відсутності екстемпорально виготовлених розчинів калію йодиду можливе виготовлення перорального

Таблиця 3

Дози калію йодиду для різних вікових груп населення

\begin{tabular}{|c|c|c|c|c|c|}
\hline Вікова група & $\begin{array}{c}\text { Доза йоду, } \\
\text { мг }\end{array}$ & $\begin{array}{c}\text { Доза KI, } \\
\text { мг }\end{array}$ & $\begin{array}{c}\text { Таблетки KI } \\
\text { (250 мг) }\end{array}$ & $\begin{array}{c}\text { Розчин КІ } \\
0,32 \%-10 \text { мл }\end{array}$ & $\begin{array}{c}\text { Розчин КІ } \\
0,65 \%-100 \text { мл }\end{array}$ \\
\hline $\begin{array}{l}\text { Дорослі та діти від } \\
12 \text { років }\end{array}$ & 100 & 130 & $1 / 2$ & - & $\begin{array}{c}20 \text { мл } \\
\text { (4 чайні лож.) }\end{array}$ \\
\hline Діти (від 3 до 12 років) & 50 & 65 & $1 / 4$ & - & $\begin{array}{c}10 \text { мл } \\
\text { (2 чайні лож.) }\end{array}$ \\
\hline $\begin{array}{l}\text { Діти (від } 1 \text { місяця до } \\
3 \text { років) }\end{array}$ & 25 & 32 & $\begin{array}{c}1 / 8 \\
\text { Рекомендовано розчин } \\
\text { КІ 0,32\% або 0,65\% } \\
\end{array}$ & $\begin{array}{c}10 \text { мл } \\
\text { (2 чайні лож.) }\end{array}$ & $\begin{array}{c}5 \text { мл } \\
\text { (1 чайна лож.) }\end{array}$ \\
\hline $\begin{array}{l}\text { Немовлята (від } \\
\text { народження до } 1 \text { місяця) }\end{array}$ & 12,5 & 16 & $\begin{array}{c}1 / 16 \\
\text { Рекомендовано розчин } \\
\text { KI 0,32\% }\end{array}$ & $\begin{array}{c}5 \text { мл } \\
\text { (1 чайна лож.) }\end{array}$ & - \\
\hline
\end{tabular}

ISSN 2312-0967. Pharmaceutical review. 2020. № 1 
Фармацевтична технологія, біофармація, гомеопатія Pharmaceutical technology, biopharmacy, homeopathy

розчину з таблеток калію йодиду по 250 мг у домашніх умовах.

3 цією метою одну таблетку калію йодиду по 250 мг подрібнюють до однорідної порошкової маси, додають 4 чайні ложки (20 мл) прокип'яченої та охолодженої води питної і перемішують до однорідної. До одержаної суміші додають 4 чайні ложки (20 мл) фрруктового сиропу для маскування солоно-гіркого смаку калію йодиду, перемішують до однорідності. В одній чайній ложці суміші буде 32 мг калію йодиду.

Для немовлят віком від народження до 1 місяця одну таблетку калію йодиду по 250 мг подрібнюють до однорідної порошкової маси, додають 8 чайних ложок (40 мл) прокип'яченої і охолодженої води питної і перемішують до однорідності. До одержаної суміші додають ще 8 чайних ложок (40 мл) прокип'яченої і охолодженої води питної, перемішують до однорідності. В одній чайній ложці суміші буде 16 мг калію йодиду.
Висновок. У результаті аналізу національних нормативних документів встановлена відсутність регламенту проведення йодної профрілактики у випадку РА для різних вікових категорій населення, яке проживає у безпосередньо близько до AEC. Встановлено відсутність на українському фрармацевтичному ринку препаратів калію йодиду для захисту новонароджених та дітей до 3-х років від радіаційних уражень щитоподібної залози. 3 урахуванням міжнародних (МАГАТЕ, ВОО3, FDA) та національних вимог, досвіду інших країн, обґрунтовано необхідність розробки рідких пероральних лікарських засобів із калію йодидом промислового виробництва або екстемпорального виготовлення для проведення йодної профрілактики дітям віком від народження до 3 років.

Конфлікт інтересів: відсутній.

Conflicts of interest: authors have no conflict of interest to declare.

\title{
RATIONALE FOR PHARMACEUTICAL DEVELOPMENT OF MEDICINAL PRODUCTS FOR THE PERFORMANCE OF IODIC PREVENTION OF RADIATION IN CHILDREN
}

\author{
D. V. Voronenko ${ }^{1}$, T. A. Shostak ${ }^{2}$, S. B. Bilous ${ }^{2}$, P. V. Oliinyk ${ }^{2}$ \\ ${ }^{1}$ Ukrainian Military Medical Academy, Kyiv \\ ${ }^{2}$ Danylo Halytskyi Lviv National Medical University \\ petrolinik1@gmail.com
}

The aim of the work. Substantiation of the need to expand the range of medicines for iodine prophylaxis in case of radiation accidents.

Materials and Methods. The methods of information search, systematization, content analysis, comparison and generalization were applied.

Results and Discussion. According to the analysis of the assortment of potassium iodide remedies as of December 1,2019 , it is established that 30 positions with potassium iodide in the form of 7 dosage forms have been registered in the Ukrainian pharmaceutical market. The registered drugs are intended for the treatment of thyroid diseases and the prevention of iodine deficiency and contain a dose of stable iodine of 100-200 mcg, which is not enough for the prevention of radiation damage. The necessity of development of liquid potassium iodide medicines in the form of oral solution of extemporaneous or industrial manufacture for carrying out iodine prophylaxis for the infant population and children in maternity hospitals, children's hospitals and other children's institutions is substantiated. The introduction of industrial production of oral solution with a potassium iodide concentration of $65 \mathrm{mg} / \mathrm{ml}(6.5 \%)$ is proposed. Pharmacies with the right to extramural drug production in the event of receiving a radiation accident are suggested to produce $0.65 \%$ and $0.32 \%$ solution of potassium iodide for the prevention of radiation damage in children of all ages.

Conclusions. The absence of potassium iodide preparations on the Ukrainian pharmaceutical market for the protection of newborns and children under 3 years of age from radiation damage to the thyroid gland. Taking into account international and national requirements the necessity of development of liquid oral medicines with potassium iodide of industrial production or extemporal manufacture for carrying out iodine prophylaxis for children from birth to 3 years is substantiated.

Key words: radiation accident; iodine prophylaxis; newborns and infants; potassium iodide.

ISSN 2312-0967. Фармацевтичний часопис. 2020. № 1 


\title{
ОБОСНОВАНИЕ ФАРМАЦЕВТИЧЕСКОЙ РАЗРАБОТКИ ЛЕКАРСТВЕННОГО СРЕДСТВА ДЛЯ ПРОВЕДЕНИЯ ЙОДНОЙ ПРОФИЛАКТИКИ РАДИАЦИОННЫХ ПОРАЖЕНИЙ У ДЕТЕЙ
}

\author{
Д. В. Вороненкоㄹ, Т. А. Шостак², С. Б. Билоус², П. В. Олийнык² \\ Украинская военно-медицинская академия ${ }^{1}$, Киев \\ Львовский национальный медицинский университет имени Данила Галицкого \\ petrolinik1@gmail.com
}

Цель работы. Обоснование необходимости расширения ассортимента лекарственных средств для йодной профилактики в случае радиационных аварий.

Материалы и методы. Применяли методы информационного поиска, систематизации, контент-анализа, сравнения и обобщения.

Результаты и обсуждение. По результатам анализа ассортимента препаратов с калия йодидом по состоянию на 1 декабря 2019 года установлено, что на украинском фрармацевтическом рынке зарегистрировано 30 позиций с калия йодидом в виде 7 лекарственных форм. Зарегистрированные препараты предназначены для лечения заболеваний щитовидной железы и профилактики йодного десицита и содержат дозу стабильного йода 100-200 мкг, что недостаточно для просилактики радиационных поражений. Обоснована необходимость разработки жидких лекарственных средств с калия йодидом экстемпорального изготовления или промышленного производства для проведения йодной профилактики детскому населению и детям в родильных домах, детских больницах и других детских учреждениях. Предложено введение промышленного производства перорального раствора с концентрацией калия йодида 65 мг / мл (6,5 \%). В аптеках с правом экстемпорального изготовления лекарственных средств в случае получения уведомления о радиационной аварии предложено изготавливать 0,65 \% и 0,32 \% растворы калия йодида для профилактики радиационных поражений у детей разного возраста.

Выводы. Установлено отсутствие на украинском фармацевтическом рынке препаратов калия йодида для защиты новорожденных и детей до 3-х лет от радиационных поражений щитовидной железы. С учетом международных и национальных требований обоснована необходимость разработки жидких пероральных лекарственных средств с калия йодидом промышленного производства или экстемпорального изготовления для проведения йодной просилактики детям в возрасте от рождения до 3 лет.

Ключевые слова: радиационная авария; йодная просрилактика; новорожденные дети и младенцы; калия йодид.

\section{Список бібліографрічних посилань}

1. Про затвердження Порядку здійснення невідкладних заходів йодної профрілактики серед населення України у разі виникнення радіаційної аварії: наказ Державної інспекції ядерного регулювання України № 154 від 08.11. 2011. URL: https://zakon.rada.gov.ua/ laws/ show/z1353-11

2. PAG Manual: Protective Action Guidesand Planning Guidance for Radiological Incidents. https://www.nrc. gov/docs/ML1635/ML16351A497.pdf

3. Guidance. Potassium lodide as a Thyroid Blocking Agent in Radiation Emergencies. FDA. 2001. https:// www.fda.gov/media/72510/download

4. Guidelines for lodine Prophylaxis following Nuclear Accidents. WHO. 1999. https://www.who.int/ionizing_radiation/pub_meet/lodine_Prophylaxis_guide.pdf

\section{References}

1. On approval of the Procedure for implementation of urgent measures of iodine prevention among the population of Ukraine in the event of a radiation accident. Order of the State Nuclear Regulatory Inspectorate of Ukraine No. 154 of 08.11.2011. [Про затвердження Порядку здійснення невідкладних заходів йодної профілактики серед населення України у разі виникнення радіаційної аварії. Наказ Державної
5. Медична допомога дитячому населенню при радіаційних подіях на перших етапах / Д. Є. Афранасьєв та ін. Проблеми радіаційної медицини та радіобіології. 2016. Вип. 21. С. 21- 44.

6. U.S. Food and Drug Administration. https://www.fda. gov/drugs

7. Державний реєстр лікарських засобів України. URL : http://www.drlz.kiev.ua/

8. Настанова СТ-Н МОЗУ 42-4.5:2015. Вимоги до виготовлення нестерильних лікарських засобів в умовах аптек. Київ, 2016. 109 с.

9. Настанова СТ-Н МОЗУ 42-4.6:2015. Вимоги до виготовлення стерильних та асептичних лікарських засобів в умовах аптек. Київ, 2016. 96 с.

інспекції ядерного регулювання України № 154 від 08.11.2011] Available at: https://zakon.rada.gov.ua/ laws/show/z1353-11. Ukrainian.

2. PAG Manual: Protective Action Guidesand Planning Guidance for Radiological Incidents. Available at: https://www.nrc.gov/docs/ML1635/ML16351A497.pdf

3. Guidance. Potassium lodide as a Thyroid Blocking Agent in Radiation Emergencies. FDA. 2001. Available

ISSN 2312-0967. Pharmaceutical review. 2020. № 1 
Фармацевтична технологія, біофармація, гомеопатія Pharmaceutical technology, biopharmacy, homeopathy

at: https://www.fda.gov/media/72510/download

4. Guidelines for lodine Prophylaxis following Nuclear Accidents. WHO. 1999. https://www.who.int/ionizing_radiation/pub meet/lodine Prophylaxis guide.pdf

5. Afanasiev $\bar{D}$ Ye. [Medical assistance to the infant population during radiation events in the first stages]. Problemy radiatsiinoi medytsyny ta radiobiolohii. 2016;21: 21-44. Ukrainian.

6. U.S. Food and Drug Administration. Available at: https:// www.fda.gov/drugs

7. State Register of Medicines of Ukraine [Державний реєстр лікарських засобів України]. Available at: http://www.drlz.kiev.ua/ Ukrainian.

8. Guidance. Requirements for the manufacture of non-sterile medicines in pharmacies. [Настанова СТ-Н МОЗУ 42-4.5:2015 Вимоги до виготовлення нестерильних лікарських засобів в умовах аптек] Kyiv; 2015. Ukrainian.

9. Guidance. Requirements for the manufacture of sterile and aseptic drugs in pharmacies. [Настанова СТ-Н МО3У 42-4.6:2015. Вимоги до виготовлення стерильних та асептичних лікарських засобів в умовах аптек] Kyiv; 2015. Ukrainian.

\section{Відомості про авторів}

Вороненко Д. В. - магістр фрармації, старший викладач кафредри військової фрармації, Українська військово-медична академія, Київ, Україна. Email: dvork226@ukr.net, ORCID: 0000-0002-6186-0800.

Шостак Т. А. - канд. фрармац. н., асистент кафедри технології ліків і біофармації, Львівський національний медичний університет імені Данила Галицького, Львів, Україна. E-mail: t_shostak8@ukr.net, ORCID: 0000-0002-9679-0400.

Білоус С. Б. - д. фрармац. н., доцент, завідувач кафедри технології ліків і біофармації, Львівський національний медичний університет імені Данила Галицького, Львів, Україна. E-mail: svitlana.bilous@gmail.com, ORCID: 00000002-1682-5352.

Олійник П. В. - д. фрармац. наук, профресор кафедри медицини катастрофр та військової медицини, Львівський національний медичний університет імені Данила Галицького, Львів, Україна. Email: petrolinik1@gmail.com, ORCID: 0000-0001-6686-6382.

\section{Information about the authors}

Voronenko D. V. - Master of Pharmacy, Senior Lecturer of the Department of Military Pharmacy, Ukrainian Military Medical Academy, Kyiv, Ukraine. Email: dvork226@ukr.net, ORCID: 0000-0002-6186-0800.

Shostak T. A. - PhD (Pharmacy), Assistant, Department of Drug Technology and Biopharmaceutics, Danylo Halytskyi Lviv National Medical University, Ukraine. Email: t_shostak8@ukr.net, ORCID: 0000-0002-9679-0400.

Bilous S. B. - DS (Pharmacy), Associate Professor, Head of the Department of Drug Technology and Biopharmaceutics, Danylo Halytskyi Lviv National Medical University, Ukraine. Email: svitlana.bilous@gmail.com, ORCID: 0000-0002-16825352.

Oliinyk P. V. - DS (Pharmacy), Professor of the Department of Disaster Medicine and Military Medicine, Danylo Halytskyi Lviv National Medical University, Lviv, Ukraine. Email: petrolinik1@gmail.com, ORCID: 0000-0001-6686-6382. 